Revista NEP - Núcleo de Estudos Paranaenses, Curitiba, v.5, n.1, jun. 2019

\title{
OS CRIMES DO CAPITÃO-MOR DE SÃO FRANCISCO DO SUL DOMINGOS FRANCISCO FRANCISQUES, VULGO "CABECINHA"
}

\author{
Fernando Hinsching ${ }^{1}$ \\ Rafael José Nogueira ${ }^{2}$ \\ Ian Pogan ${ }^{3}$
}

\begin{abstract}
Resumo: O capitão-mor Domingos Francisco Francisques, que acabou ficando mais conhecido na cidade de São Francisco do Sul por "Cabecinha" ficou marcado na memória social de São Francisco do Sul como o autor de vários crimes horríveis e hediondos e sem contar suas ações tirânicas e abusivas. Vamos mapear a atuação do personagem começando por analisar os estudos mais antigos de Lucas Alexandre Boiteux (1912), Luís Gualberto (1958) e mais recentemente o trabalho de Carlos da Costa Pereira (1984). A partir de suas hipóteses entrelaçadas com a documentação primária ancorada em cartas do período buscaremos pontuar suas ações. A primeira carta é de 1712 do Rei Dom João V ao governador da praça de Santos onde ele explicita estar ciente dos crimes de Cabecinha. A segunda a terceira carta juntamente com a sentença em 1721 é do ouvidor de São Paulo Rafael Pires Pardinho que detalha todos os passos de "Cabecinha" e qual foi seu julgamento e sentença diante de tudo que levantou e analisou relativo as acusações que teve em suas mãos. Indo por esses dois caminhos pretendemos fundamentar nossa análise mapeando suas ações criminosas, relacionando metodologia, teoria e fontes primárias. A genealogia de "Cabecinha" e sua família será outro caminho que usaremos para entender as nuances do personagem e de que forma ele se inseriu no contexto do qual resultou seus crimes. Nos afastaremos um pouco das lendas e mitos não por considerarmos irrelevantes, mas exatamente por entendermos que ela necessita de mais espaço para a análise.
\end{abstract}

Palavras chave: Genealogia, "Cabecinha”, memória, crimes.

\section{THE CRIMES OF CAPTAIN-MAJOR OF SAN FRANCISCO DEL SUR DOMINGOS FRANCISCO FRANCISQUES, COMMONLY KNOWN AS "CABECINHA"}

\begin{abstract}
Captain-Major Domingos Francisco Francisques, who became better known in the city of São Francisco do Sul for "Cabecinha" was marked in the social memory of San Francisco do Sul as the author of several horrible and heinous crimes and not counting his tyrannical actions and abusive. We will map the performance of the character beginning with analyzing the oldest studies of Lucas Alexandre Boiteux (1912), Luís Gualberto (1958) and more recently the work of Carlos da Costa Pereira (1984). From their hypotheses intertwined with the primary documentation anchored in letters of the period we will seek to punctuate their actions. The first letter is from 1712 of King Dom João V to the governor of the square of Santos where he explicitly be aware of the crimes of Cabecinha. The second to third letter together with the sentence in 1721 is of the São Paulo ombudsman Rafael Pires Pardinho which details all the steps of "Cabecinha" and what was his judgment and sentence before all that he raised and analyzed concerning the

\footnotetext{
1 Bacharel em sistemas de informação - Unisociesc. Contato: hinsching@ gmail.com

${ }^{2}$ Graduado em História - Univille. Contato: rjnra@ hotmail.com

${ }^{3}$ Graduando em História - Univille. Contato: campodoirani@ gmail.com
} 
Revista NEP - Núcleo de Estudos Paranaenses, Curitiba, v.5, n.1, jun. 2019

accusations he had in his hands. Going through these two paths we intend to base our analysis by mapping their criminal actions, relating methodology, theory and primary sources. The genealogy of "Cabecinha" and his family will be another way that we will use to understand the nuances of the character and in what way he inserted in the context of which resulted his crimes. We will depart somewhat from legends and myths not because we consider it irrelevant, but precisely because we understand that it needs more space for analysis.

Key words: Genealogy, "Cabecinha”, memory, crimes.

\section{Introdução}

Qualquer pesquisador que busque investigar os passos de Domingos Francisco Francisques certamente vai se deparar na sua empreitada com lendas, mitos, memórias orais e boatos que andam junto com o personagem conhecido como "Cabecinha". Há muito tempo "Cabecinha" descolou sua imagem de um Capitão-mor para se tornar uma personalidade recheada de mistérios, obscuridades, questões não respondidas e principalmente incertezas. O passado e sua interpretação como negócio tem como moeda de troca o sentido da subjetividade. Assinala a relação entre lembrança e esquecimento na construção da ciência histórica. Iremos na direção de distinguir aquilo que se configurou como um discurso romanesco e sem se preocupar com fundamento histórico, mas que de certa forma engendra possibilidades de entender como a cidade se vê na história ou melhor na memória e o que podemos avaliar como uma interpretação ancorada em um embasamento documental e metodológico.

Qual a relevância então que justifica o presente trabalho? Cremos que podemos resumir em dois pontos a indagação. Entender a história do Brasil no período Colonial passa por entender as ações dos agentes que ocupavam posições de destaque e que tinham a tarefa de tomar decisões fazendo cálculos políticos que não geravam necessariamente uma relação de causalidade com as transformações socioculturais e econômicas do nosso território, mas que sem dúvida despertavam e engendravam meios para novos processos históricos. Aqui chegamos ao segundo ponto. Examinar os atos de "Cabecinha" pode parecer mais um estudo isolado para atender a uma demanda da história local e estadual sem conexão com a história do Brasil. Se avaliarmos com mais rigor vamos compreender que a questão se coloca num nível mais profundo. O que isso quer dizer? Nenhuma das obras de "Cabecinha" era isolada e sim estava alinhada dentro de um universo mais amplo 
Revista NEP - Núcleo de Estudos Paranaenses, Curitiba, v.5, n.1, jun. 2019

e alicerçado em três grandes pontos: laços familiares, riqueza e poder político. Tudo o que o nosso personagem fazia era em consonância com práticas corriqueiras no restante do país. Um candidato a potentado local que se prezasse começava por herdar uma família influente. Caso não viesse de uma se aliava, depois com recursos na mão ia pavimentando seu caminho comprando títulos, patentes e apoio e por fim chegava ao desejado poder político sobre o local que almejava.

Partindo dessas premissas na primeira parte iniciaremos com uma apresentação dos genealógicos que dispomos de "Cabecinha" para tentar traçar sua descendência, além da sua chegada ao posto de Capitão-mor, bem como os crimes que são atribuídos a ele e que rodeiam o imaginário de seus atos. Em seguida iremos nos concentrar no exame do nosso corpo documental formado por cartas da época e estudos raros e preciosos sobre a personalidade em questão. Sobretudo vamos avaliar a carta relatando os crimes juntamente com a sentença do Ouvidor-mor Rafael Pires Pardinho de 1721 enviados ao rei Dom João V e a Relação da Bahia. Além das fontes primárias supracitadas, nossa principal referência é o livro História de São Francisco do Sul do escritor francisquense Carlos da Costa Pereira. Sua obra é vital para o nosso trabalho ainda que não seja de um historiador de formação. A sentença dada a "Cabecinha" e seus cumplices será também objeto de análise. Na parte final do texto temos as tentativas de prisão de "Cabecinha" e seus partidários deixando em aberto a questão pela falta de informações do seu paradeiro. E para fechar a análise um balanço dos resultados alcançados e o que fícou de dúvidas para responder em trabalhos futuros.

Cumpre esclarecer depois de apresentar nosso material empírico que nos guiamos pelo método indiciário delineado por Carlo Ginzburg em suas obras. O paradigma indiciário busca valorizar as individualidades do objeto de estuado reconhecendo sua complexidade e usando como princípio concluir que uma causa é advinda de um efeito e não o contrário. Dito de outra forma a correlação não implica em causalidade, mas sim os efeitos surgem a partir das causas. $O$ historiador que se vale do método indiciário deve sempre saber que o método em questão é um trabalho interpretativo que envolve várias áreas dentro do campo da microanálise. Para isso é fundamento a multiplicidade documental. Nesse sentido é preciso separar o caráter metodológico de observação numa escala micro do lugar e contexto do objeto estudado 
Revista NEP - Núcleo de Estudos Paranaenses, Curitiba, v.5, n.1, jun. 2019

em si. O resultado final da pesquisa com o método indiciário dependerá do nível de estudo exaustivo e minucioso das fontes arroladas.

Dado a devida atenção a justificativa e as concepções metodológicas vamos nos debruçar o tema articulando metodologia, material empírico e a nossa percepção teórica apoiada em Raymundo Faoro com o seu livro "Os Donos do Poder" que traz os conceitos de estamentos e patrimonialismo que será um guia para o nosso trabalho.

\section{Genealogia e chegada ao posto de Capitão-mor}

A descendência do nosso personagem já foi preliminarmente por Antonio Roberto Nascimento ${ }^{4}$.Era filho de Violante Rodrigues Velha e Ângelo Francisco Francisques. A mãe de "Cabecinha" Violante era filha de Luís Rodrigues Cavalhinho e Isabel Rodrigues Velho. A vó de "Cabecinha" a referida Isabel Rodrigues Velho era filha de Maria Coqueiro, Cousseiro, Conqueiro ou talvez Conquera e do fundador de São Francisco do Sul Manoel Lourenço de Andrade. Portanto Domingos Francisco Francisques alcunha de "Cabecinha" era bisneto pelo lado materno de Manoel Lourenço de Andrade fundador e primeiro Capitão-mor de São Francisco do Sul. É de se destacar que "Cabecinha" teve como irmãos biológicos e cumplices em suas desventuras Antonio Francisco Francisques, José Francisco Francisques e provavelmente Miguel Francisco Francisques. O personagem "Cabecinha" também deixou descendentes com sua esposa do qual não sabemos o nome apenas suspeita que era mameluca. Seus filhos foram: Domingos Francisco Francisques, o moço; Ângelo Francisco Francisques, neto; Timóteo Francisco Francisques; Violante Rodrigues Velha. Há dúvida se o tal José Francisco Francisques era irmão como dissemos ou filho. Infelizmente pela perda dos livros de batismo e óbitos da Igreja de São Francisco do Sul não contamos com datas e ficamos impossibilitados de uma cronologia mais apurada, inclusive sobre a questão de quando ele assumiu o posto de Capitão-mor. ${ }^{5}$

A genealogia vem se tornando uma ferramenta cada vez mais presente para se compreender como os indivíduos se colocam em determinados contextos. Com a

\footnotetext{
${ }^{4}$ NASCIMENTO, Antonio Roberto. A descendência do Fundador de São Francisco do Sul. Revista do Instituto Histórico e Geográfico de Santa Catarina, Florianópolis, n.17, p. 9-39, jan. 1998. p. 25-30

${ }^{5}$ NASCIMENTO, 1998. p. 27.
} 
Revista NEP - Núcleo de Estudos Paranaenses, Curitiba, v.5, n.1, jun. 2019

popularização da genealogia vem ocorrendo uma aproximação com o público. Para alguns autores os registros genealógicos não deixam de ter rigor e validade e podem ser vistos por um prisma cientifico: “A genealogia é, pois, uma ciência que tem nos arquivos o seu laboratório" ". Essa concepção é influenciada também pelos Annales que alargou a noção de documento e viu na família um vestígio a ser examinado.

Não temos com precisão a informação de quando "Cabecinha" foi nomeado Capitão-mor da Vila de São Francisco do Sul.

O que fazer diante da incerteza? O historiador Carlo Ginzburg nos dá uma possibilidade metodológica para inferirmos algumas suposições. Pois: "Se a realidade é opaca, existem zonas privilegiadas - sinais, indícios - que permitem decifrá-la"7. Confrontando a seguir algumas datas de diferentes fontes chegamos a uma ideia aproximada.

Costa Pereira afirma que em 14 de fevereiro de 1666 Gabriel de Lara sucedeu a Manoel Lourenço de Andrade após sua morte e diz em relação a "Cabecinha" apoiado pelo Livro das Novidades ${ }^{8}$ que: "Anos depois, Domingos Francisco Francisques, cognominado $O$ "Cabecinha”, assumia as funções de capitão-mor de São Francisco, na qualidade de representante e locotenente do Marquês de Cascais". ${ }^{9}$ Ele não apresenta uma data ou uma estimativa de quando "Cabecinha" teria assumido o posto de capitão-mor. Na sentença de 1721 de Rafael Pires Pardinho que iremos estudar mais profundamente a frente diz ao rei Dom João V o seguinte sobre a questão:

O que tudo visto e o que mais dos autos se mostra. E como pela devassa de Residência que ao réu Domingos Francisco Francisques se tirou na dita [Vila] de Nossa [Senhora] da Graça se prova que este nela serviu vinte e sete [para] vinte e oito anos de [Capitão-mor] por Alvará do Marquês de Cascaes, Dom Luis Álvares de Castro e Souza, que foi donatário daquela vila, sem mais

\footnotetext{
${ }^{6}$ GUERRA, Luís Bivar. Cem anos de Genealogia (1877-1977). Lisboa: Biblioteca genealógica de Lisboa, 1978. p. 171.

${ }^{7}$ GINZBURG, Carlo. "Sinais: raízes de um paradigma indiciário" In: Mitos, emblemas, sinais: Morfologia e História. $1^{a}$ reimpressão. São Paulo: Companhia das Letras, 1990. p. 177.

${ }^{8}$ O Livro das Novidades ou memória anuais foi criada pela Rainha Dona Maria I em 1782 como uma espécie de livro de memória e registros dos acontecimentos mais relevantes nas ouvidorias e suas vilas. Carlos da Costa Pereira em nota de rodapé comenta que o Livro das Novidades de São Francisco do Sul desapareceu da câmara de São Francisco do Sul e suspeita-se que teria sido extraviado por um presidente da província de Santa Catarina em meados do século 19 quando esteve na cidade.

9 PEREIRA, Carlos da Costa. História de São Francisco do Sul. Florianópolis: Ed. da UFSC; São Francisco do Sul, SC: Prefeitura Municipal, 1984. p. 55-56.
} 
Revista NEP - Núcleo de Estudos Paranaenses, Curitiba, v.5, n.1, jun. 2019

confirmação do dito senhor, como era obrigado atirar com a nomeação do dito Marquês, com a qual [somente] continuou a servir tantos anos contra as ordens do dito senhor, que proíbem servirem os Capitães-mores mais de três anos. ${ }^{10}$

Pelo que consta na peça produzida por Pires Pardinho ele serviu de 27 a 28 anos como capitão-mor e sem a autorização do Marquês de Cascais, pois a priori um capitãomor não poderia servir mais do que três anos conforme é dito nas Ordenações Filipinas que desde 1603 regulamentava a questão: “[...] Servirá o dito oficio por três anos, e mais não; os quais acabados, se fará outro na maneira sobredita. [... $]^{11}$. A coroa parecia se preocupar com o fato de que pudessem haver capitães que almejassem de se perpetuar no poder por vários anos. Segundo Costa Pereira é precisa lembrar que em São Francisco e outras donatarias da ouvidoria de São Paulo o Capitão-mor era escolhido por nomeação exclusiva do donatário, o que explicaria o caso destoante de "Cabecinha" com quase trinta anos à frente da função de capitão-mor. Só com a correição de 1720 realizada por Pires Pardinho é que foi regulamentada esse ponto através de eleições para a ocupação do cargo. Com a informação de que "Cabecinha” ficou quase três décadas como capitão-mor de São Francisco podemos fazer uma estimativa em que ano ele assumiu.

Antes de Pires Pardinho estar em São Francisco entre 1720 e 1721 para deixar as correições e julgar o caso de "Cabecinha", Costa Pereira afirma que muitos anos antes ele já não estava mais governando na condição de capitão-mor: “[...] o "Cabecinha” já havia sido destituído do cargo de capitão-mor, que passara a ser exercido por Agostinho Alves Marinho, com que o Sargento-mor Manoel Gonçalves de Aguiar se entendera, quando da sua passagem por aqui, a 3 de março de 1711 ". ${ }^{12}$ Partindo da hipótese que ele ficou no posto até 1710 aproximadamente já que em 1711 estava foragido da justiça podemos supor que ele ascendeu ao cargo em 1682 ou 1683, claro isso no campo da estimativa e com os dados que citamos acima de que ele teria ficado entre 27 e 28 anos como Capitão-mor. Uma informação que dá força a nossa hipótese é o registro de Luis Gualberto que diz “Cabecinha” ser Capitão-mor já em 1686. Nas suas palavras: “[...] além de capitão-mor que já o era em 1686, locotenente, sesmeiro e procurador bastante do

${ }^{10}$ 1721, agosto, 26, Paranaguá, CARTA do (ouvidor-geral da capitania de São Paulo), Rafael Pires Pardinho juntamente com a cópia da sentença que proferiu para (o rei) Dom João V. AHU, CU, 02301, Cx. 2, D. 202.

${ }^{11}$ ORDENAÇÕES FILIPINAS. Lisboa: Calouste Gulbenkian, 1984. p. 172.

${ }^{12}$ Id. Ibid, p. 59. 
Revista NEP - Núcleo de Estudos Paranaenses, Curitiba, v.5, n.1, jun. 2019

Marquês de Cascais, nesta sua Capitania do Rio de São Francisco, seu distrito e em toda a sua Repartição da banda do sul'. ${ }^{13}$ Com a data aproximada cremos que nossa conjectura tenha fundamento. Vale ressaltar a reflexão de Carlo Ginzburg sobre o trabalho do historiador de tentar continuamente diagnosticar o que ninguém vê:

Trata-se de formas de saber tendencialmente mudas - no sentido de que, como já dissemos, suas regras não se prestam a ser formalizadas nem ditas. Ninguém aprende o oficio de conhecedor ou de diagnosticador limitando-se a pôr em prática regras preexistentes. Nesse tipo de conhecimento entram em jogo (dizse normalmente) elementos imponderáveis: faro, golpe de vista, intuição ${ }^{14}$.

Esses elementos elencados por Carlo Ginzburg são geralmente mal vistos dentro da metodologia cientifica e relegam um julgamento ao pesquisador que se apropria deles. Carlo Ginzburg vai em outra direção e enxerga um dilema nas ciências humanas. O dilema flutua entre um discurso cientifico frágil para obter resultados mais relevantes e não ficarmos eternamente com a sensação de que as ciências humanas estão em crise, ou reivindicar um ideário cientifico rígido e como pena chegar a poucos resultados importantes e ficar com o receio permanente de crise nas ciências humanas. ${ }^{15}$

Depois de falarmos um pouco de como "Cabecinha" se tornou Capitão-mor em São Francisco do Sul e uma suposição do período que esteve à frente do cargo vamos na próxima parte apresentar seus crimes.

\section{Crimes do capitão-mor Domingos Francisco Francisques e seus asseclas}

Em meio a tantas memórias e lembranças fragmentadas é difícil dizer quais foram exatamente os crimes que "Cabecinha" foi acusado de modo conciso e claro. Com as cartas e sentença de Pires Pardinho juntamente com a obra de Costa Pereira e outros estudos vamos construir uma cronologia dos crimes atribuídos a "Cabecinha" de modo

\footnotetext{
${ }^{13}$ GUALBERTO, Luís. Domingos Francisco Francisques. O Estado, Florianópolis, p. 7, 23 Fev. 1958.

${ }^{14}$ GINZBURG, 1990. p. 179.

${ }^{15}$ GINZBURG, 1990, 178.
} 
que fique menos complexo e mais inteligível o que tem alguma veracidade e o que só continua sendo lenda.

Antes é preciso conhecer um pouco o contexto em que aconteceram os crimes. Principalmente as narrativas que vieram até nós.

Para Costa Pereira: "Domingos Francisco Francisques exerceu em São Francisco verdadeira tirania, cometendo atos os mais bárbaros que, pelo requinte de perversidade de que se revestiam, jamais puderam ficar esquecidos na memória do povo" ${ }^{16}$. O ouvidor-geral Rafael Pires Pardinho vai na mesma direção ao relatar o perfil de "Cabecinha" ainda que testemunhas tenham feito falas favoráveis ao agora réu em 1721:

(...) se prova que o réu naquela [vila] fora turbulento homem e de pouca razão, amigo de bulhas e de ousadias que fomentava entre os mesmos moradores e pessoas que de fora eram aquela [vila] nas embarcações com seu negócio aos quais se mostra também, tomava fazendas fiadas e se lhe pediam a paga os chegava a espancar, e corria com que não tornava à terra. ${ }^{17}$

Todos esses desmandos e tiranias permaneceram na memória local da cidade entre seus moradores até os dias atuais. As atribuições de um Capitão-mor estimulavam "Cabecinha" a agir de forma arbitrária. Para se ter uma noção do poder do Capitão-mor ele cuida força policial, das obras públicas, Chefe das ordenanças e tinha papel fundamental na resolução de problemas importante juntamente com a Câmara. Por mais que fosse um cargo sem salário era muito visado tamanho o poder que o indivíduo ganhava. Todos lhes deviam obediência. Contudo não era uma função que qualquer um tinha chance de alcançar. Era necessário ter linhagem nobre e fortuna, ou seja, fazer parte dos homens bons $^{18}$. Somado a isso Costa Pereira reflete sobre o contexto que ajudava a criar tipos como "Cabecinha":

O meio, a época e a circunstância de encontrar-se vila dentro dos domínios de uma donataria até pouco antes em litigio, tudo contribuía para acoroçoar o "Cabecinha" a exercer vinganças pessoais, a fazer sentir direta e

\footnotetext{
${ }^{16}$ PEREIRA, 1984, p. 56.

${ }^{17}$ PARDINHO, 1721, p. 4.

${ }^{18}$ O sociólogo Ricardo da Costa Oliveira apresenta em seu trabalho o documento com a lista de 45 nomes de candidatos a Homens Bons para a vila de São Francisco do Sul. Para ver mais: OLIVEIRA, Ricardo Costa de. 'Homens Bons' da Vila de Nossa Senhora da Graça do Rio de São Francisco do Sul. Uma 'Elite Senhoril' do Brasil Meridional nos séculos XVIII e XIX. Revista do Arquivo Histórico de Joinville, Joinville (SC), v.1, n.1, p. 127-154, dez. 2007.
} 
Revista NEP - Núcleo de Estudos Paranaenses, Curitiba, v.5, n.1, jun. 2019

flagrantemente os poderes de que se achava investido, a impor-se com arrogância e com orgulho no ânimo público, submetendo-se todas às injunções do momento, sem terem para quem apelar". ${ }^{19}$

Sem esquecer da distância da ouvidoria com a vila e falta de correição e provimentos que só viriam em 1720 com Rafael Pires Pardinho que engendraram circunstancias para que "Cabecinha" reinasse soberano sem ser punido por seus crimes durante muitos anos.

O jurista Raymundo Faoro em sua famosa obra Os Donos do Poder postula que as raízes das mazelas do nosso país residem na herança patrimonialista da Coroa portuguesa onde essa herança se tornou um padrão institucional na durante a Colônia. Portanto como dissemos na introdução a trajetória de "Cabecinha" não estava desligada do contexto nacional e ele não fazia questão de esconder sua forma patrimonialista de poder. Raymundo Faoro explica a gênese do patrimonialismo português assim:

\begin{abstract}
A coroa conseguiu formar, desde os primeiros golpes da reconquista, imenso patrimônio rural (bens "requengos", "regalengos", "regoengos", "regeengos"), cuja propriedade se confundia com o domínio da casa real, aplicado o produto nas necessidades coletivas ou pessoais, sob as circunstâncias que distinguiam mal o bem público do bem particular, privativo do príncipe [...] A propriedade do rei - suas terras e seus tesouros - e confundem nos seus aspectos público e particular. Rendas e despesas se aplicam, sem discriminação normativa prévia, nos gastos da família ou em bens e serviços de utilidade geral $^{20}$
\end{abstract}

A presença do Estado sempre foi presenta na história do Brasil na visão de Raymundo Faoro. O primeiro crime que iremos analisar mostra bem como "Cabecinha" usava o patrimonialismo para seus interesses.

Dentro os seus crimes vamos começar por analisar pelo conflito com Frei Antônio e o suposto sequestro do vigário Frei Fernando. Diz a sentença de Pires Pardinho que "Cabecinha" afastou da Vila Frei Antonio que era frade de São Francisco, pretendendo mata-lo o forçando a fugir pelas matas. ${ }^{21}$ Não temos mais notícias sobre o fato. No Livro das novidades estaria registrado conforma assevera Costa Pereira que "Cabecinha" fez uma resolução mandando preparar uma canoa velha para nela colocar

\footnotetext{
${ }^{19}$ PEREIRA, 1984, p. 56.

${ }^{20}$ FAORO, Raymundo. Os Donos do Poder. Formação do patronato político brasileiro. 2 vol. 4 ed. Porto Alegre: Globo, 1977. p. 14 e 17.

${ }^{21}$ PARDINHO, 1721, p. 4.
} 
desta vez o pároco da Vila Frei Fernando. Nitidamente "Cabecinha" usou do espaço público para um desejo privado. Ele incorporava bem o patrimonialismo português. É provável que tenha sido logo depois da fuga do Frei Antonio, pois a vila ficou sem vigário e Frei Fernando pode ter assumido para o cargo não ficar vazio. O objetivo era largar a canoa com o vigário amarrado acompanhando de alguns peixes secos e um pouco de farinha. $\mathrm{O}$ motivo seria que Frei Fernando não permitiu que fosse enterrado junto a igreja o neto ${ }^{22}$ falecido de "Cabecinha" mesmo ele justificando o pedindo ao dizer que ajudou na construção da matriz.

Em relação a sentença de Pires Pardinho se obtém a informação de que "Cabecinha" perseguiu o Frei Fernando que para se salvar contou com a ajuda do sargento-mor da praça de Santos Manoel Gonçalves de Aguiar que: "Aquela vila chegara pelo réu lhe ter impedido os caminhos [para] o não poder fazer" ${ }^{23}$. Podemos presumir que esse fato envolvendo os religiosos ocorreu em março de $1711^{24}$ quando o citado Sargentomor Manoel Gonçalves esteve na vila de São Francisco pela primeira vez ou entre 1714 e 1715 quando da sua segunda e terceira passagem pela vila. Pires Pardinho segue relatando que não há como culpar o réu pelos crimes contra os sacerdotes sem os devidos procedimentos a serem tomadas para aplicar as penas previstas nas Ordenações Filipinas. Contudo isso não o eximia do quanto terrível tinha sido sua administração e que haviam outros crimes devidamente provados. ${ }^{25}$ Ainda sobre a questão envolvendo Frei Fernando, Costa Pereira questiona a veracidade do caso ao se referir sobre as tais testemunhas ouvidas por Pires Pardinho que o autor considera suspeitas e que podem ter ocultado a verdade sobre o que teria acontecido realmente com o Frei Fernando. É algo que talvez nunca tenhamos a resposta exata. $\mathrm{O}$ autor em uma nota de rodapé destaca que no Amazonas teria ocorrido um caso muito parecido com um Frei chamado Rafael.

\footnotetext{
${ }^{22}$ Na memória oral é dito que foi o filho de "Cabecinha" e não seu neto. Contudo na carta de Pires Pardinho ao soberano Dom João V em 1721 diz que se tratava um neto de "Cabecinha" fruto do enlace entre uma negra e do seu filho bastardo.

${ }^{23}$ PARDINHO, 1721. p. 5.

${ }^{24}$ Afonso de Taunay em texto ao Jornal do Comércio resgata um trecho do relato que Gonçalves Aguiar teria descrito ao governador do Rio de Janeiro sobre os desmandos na vila de São Francisco do Sul: "Homens malignos e facinorosos, soberbos e inquietadores daqueles pobres moradores, como é público e notório me fora presente por queixas". In: TAUNAY, Afonso de Escragnolle. Documentos sobre o povoamento do Rio Grande do Sul e Santa Catarina (1711). Jornal do Comércio, Rio de Janeiro, p. 4, 25 Dez. 1932.
}

${ }^{25}$ PARDINHO, op. cit. 
Coincidentemente Frei Fernando e Rafael eram da mesma ordem dos beneditinos e Costa Pereira questiona senão seria muita coincidência a semelhança nas duas narrativas.

O primeiro homicídio em que "Cabecinha" se envolveu ocorreu em 29 de setembro de 1695 e a vítima foi Pedro Gomes de Carvalho ${ }^{26}$ e está assim exposto na sentença de Pires Pardinho: “[...] Como foi a morte feita em vinte e nove de setembro de mil seiscentos e noventa e cinco, naquela [vila] a Pedro Gomes de Carvalho [...] que o réu a mandara fazer por um mulato seu escravo chamado Miguel". ${ }^{27}$ "Cabecinha" teria sido o mandante do crime depois de Pedro Gomes junto a sua sogra Catarina terem ido discutir algumas contas com Mauricio de Lima que se encontrava na casa de "Cabecinha". ${ }^{28}$ Uma das testemunhas arroladas afirmou que em conversa com "Cabecinha", o mesmo teria dito que não ordenou que seu escravo mulato Miguel matasse Pedro Gomes, mas apenas que Pedro Gomes não tinha gosto e respeito pelas leis sem nunca ter pedido que o escravo assassinasse a vítima. ${ }^{29}$ Entretanto para o ouvidor Pardinho esse evento era a prova de como o réu e seus escravos viviam de forma arrogante e sem pudor na vila de São Francisco do Sul. Frisou também que tudo que as obras de seu escravo iriam recair no réu a responsabilidade por ser dono dele e não havia como não responsabilizar "Cabecinha":

[...] Porque dando no dito Pedro Gomes o tiro fez com que sem gosto algum saísse aquela noite, e como o dito escravo não podia desgostar ao dito Pedro Gomes sem lhe fazer algum malefício, ficou o réu obrigado [pelo] seu mandato ao excesso que o seu escravo fez, ainda que [expressamente] o não mandasse matar". ${ }^{30}$

\footnotetext{
${ }^{26}$ As poucas informações sobre o dito Pedro Gomes de Carvalho vêm de Luis Gualberto em seu estudo sobre a fundação de São Francisco do Sul. O referido teria vindo no mesmo de 1695 quando do seu assassinato para São Francisco do Sul com um "[...] sortimento de fazendas, ferragens e armarinho para comerciar nas minas do rio de S. Francisco e pode ser parente de Luiz Gomes de Carvalho que, aos 12.1.1777, obteve sesmaria de 550 braças na Laguna, seguida de outras 300 em 1793". (GUALBERTO, Luiz. Contribuição para a História do Estado de Santa Catarina, Fundação de São Francisco do Sul. In: Revista Trimestral do Instituto Histórico e Geográfico de Santa Catarina, Florianópolis, n.1, v.1, 1902, p. 70)

${ }^{27}$ PARDINHO, op. cit.

${ }^{28}$ Id. Ibid.

${ }^{29}$ PARDINHO, 1721 p. 5.

${ }^{30}$ Id. Ibid.
} 
Revista NEP - Núcleo de Estudos Paranaenses, Curitiba, v.5, n.1, jun. 2019

De uma forma ou de outra o incriminado esteve envolvido na morte de Pedro Gomes de Carvalho e isso era inquestionável para Pires Pardinho. É preciso lembrar que após se tornar público a morte de Pedro Gomes de Carvalho a viúva foi se queixar com o juiz Antonio Francisco Francisques não apor acaso irmão de "Cabecinha" que sabendo de toda a história fez a devassa de modo "[...] que todos ficaram sem culpa".31 Aparentemente "Cabecinha" além de ter poder sobre tudo e todos ainda fez [sic] questão de nomear um parente seu como juiz ordinário.

Dois anos depois novamente "Cabecinha" se envolve em mais um assassinato. Dessa vez a vítima foi Mateus Afonso. Há dúvidas se foi de fato "Cabecinha" ou seu irmão Miguel Francisco Francisques. Em carta de junho de 1721 meses antes da sentença Pires Pardinho coloca que:

Também foi aprovado que um maluco, filho do réu Domingos Francisco Francisques, matara Mateus Afonso, ou a mandado de Miguel Francisco Francisques, segundo algumas testemunhas, ou do próprio réu, segundo outras. Porém, sobre isto nada de definido se pode apurar. ${ }^{32}$

Na sentença temos a informação que o assassinato aconteceu em 29 de novembro de 1697 , portando dois anos após o primeiro. O "maluco" consta como Pedro filho de "Cabecinha" e que já tinha falecido. O contexto do crime teria se dado quando Pedro a mando de "Cabecinha" foi em busca de algumas peças de ferreiro no sitio de Mateus Afonso e cumprido o pedido de seu pai e após se despedir em tom de amizade de forma traiçoeira matou Mateus com um tirou que ceifou sua vida quase que instantaneamente. O motivo teria sido a demora em fabricar e entregar as peças. ${ }^{33}$ Todavia na segunda devassa as testemunhas apontam Miguel Francisco Francisques como mandante do crime motivado por questões passionais. Já outras testemunhas indicam que o mandante foi Domingos Francisco Francisques. Irmãos e suspeitos de seres os mandantes do crime, tinham razões diferentes:

E ainda a maior [parte] das [testemunhas] digam na segunda devassa que da dita morte se tirou que a tal morte fizera de mandado de Miguel [Francisco] Francisques irmão do réu, ciúmes que este tivera do sobredito com uma

\footnotetext{
${ }^{31}$ 1721, junho, 26, Paranaguá, CARTA do (ouvidor-geral da capitania de São Paulo), Rafael Pires Pardinho (o rei) Dom João V. AHU, CU, 023-01, Cx. 2, D. 202.

${ }^{32}$ Id. Ibid.

${ }^{33}$ PARDINHO, 1721. p. 6.
} 
Revista NEP - Núcleo de Estudos Paranaenses, Curitiba, v.5, n.1, jun. 2019

bastarda sua manceba, algumas [testemunhas] também depõem fora de mandado do réu por lhe não ter feito com brevidade aquelas obras. ${ }^{34}$

Como as testemunhas ouvidas não deporão na primeira devassa por medo do réu e seus aliados inclusive familiares fica difícil concluir qual a causa do crime e quem foi de fato o mandante. ${ }^{35}$ Continua Pires Pardinho alegando que mesmo passando muitos anos dos crimes de "Cabecinha" não há possibilidade de prescrição pois está provado que o réu esteve na condição de Capitão-mor durante o período de seus crimes e por tiranizar a justiça na vila não tem o direito de prescrição que o direito, leia-se Ordenações Filipinas oferecem aos réus contra a justiça. Uma vez que "Cabecinha" podendo acusar aos réus para serem punidos não o fez. ${ }^{36}$ Ou seja, "Cabecinha" deu provas contundentes que durante o tempo que esteve à frente do posto de Capitão-mor na vila de São Francisco do Sul tentou de todas as maneiras submeter a justiça em favor dos seus interesses ou de seus amigos e familiares.

Por fim o crime mais notório em que "Cabecinha" participou: a morte dos juízes ordinários, Miguel Francisco Francisques e João Mor Vieira e claro o assassinato de Ana Lamim. Na Carta de junho de 1721 enviada de Paranaguá a Portugal não aparece a data exata. Na carta seguinte com a sentença anexada de novembro de 1721, conseguimos saber que o crime ocorreu no período da tarde e da noite de 29 de dezembro de 1713. A data corrobora a hipótese defendida por Luís Gualberto em texto publicado no jornal $O$ Estado em 1958 onde propõe que o crime teria ocorrido em fins de dezembro de 1713 usando como pista os inventários de Ana Lamim de 1 de janeiro de $1714 .{ }^{37}$

A essa altura "Cabecinha” já estava deposto do cargo de capitão-mor desde 1711 quando da vinda do Sargento-mor de Santos Manoel Gonçalves Aguiar que se encontrou com novo Capitão-mor Agostinho Alves Marinho como foi relatado anteriormente. ${ }^{38}$ Além disso o rei Dom João V já estava a par dos outros crimes de “Cabecinha” e os procedimentos para a sua prisão já tinha sido tomado em fins de 1712.

\footnotetext{
${ }^{34}$ Id. Ibid.

${ }^{35}$ Id. Ibid.

${ }^{36}$ Id. Ibid.

${ }^{37}$ GUALBERTO, Luís. 1958, p. 11.

${ }^{38}$ Não há clareza se foi destituído por ordens da Coroa ou foi a própria população que fez tal ato.
} 
Revista NEP - Núcleo de Estudos Paranaenses, Curitiba, v.5, n.1, jun. 2019

Examinando a sentença percebemos o trabalho minucioso de Pires Pardinho em apurar com imparcialidade que crimes ele deveria imputar de fato ao réu e o que deveria continuar na dúvida. Obviamente por uma questão cronológica ele não conseguia o método indiciário, contudo entreve-se que ele procura trazer a luz as pistas, ou melhor os vestígios que iriam desvelar uma realidade muito mais profunda sobre o acusado. É o que Carlo Ginzburg declara ser a semiótica médica: “[...] A disciplina que permite diagnosticas as doenças inacessíveis à observação direta na base de sintomas superficiais, às vezes irrelevantes aos olhos do leigo - o doutor Watson, por exemplo"39. É por meio dos autos de devassa (aqui considerados como pistas, indícios, sinais) que Pires Pardinho vai desnudar ou pelo menos tentar a figura de "Cabecinha". Qual é a ferramenta que ele tinha na mão para não errar diante dos autos? O direito positivado: Ordenações Filipinas. Nada fora e nada acima das Ordenações Filipinas.

Voltando ao crime é preciso destacar que há algumas interpretações divergentes e imprecisões sobre a explicação do que teria acontecido nesse dia e quais eram os interesses que ligavam os personagens ao crime. Pensamos ser necessário primeiramente identificar os indivíduos envoltos no assassinato. Temos Miguel Francisco Francisques, irmão de "Cabecinha", João Mor Vieira que é colocado como primo de "Cabecinha" por Afonso de Taunay. ${ }^{40}$ Nos trabalhos de Costa Pereira ${ }^{41}$ e Antonio Roberto Nascimento ${ }^{42}$ os autores apenas afiançam que João Mor Vieira seria sim parente, entretanto sem detalhar qual o grau. No texto de Luís Gualberto não há informação se João Mor Vieira tinha parentesco com "Cabecinha". Ambos eram juízes ordinários da vila de São Francisco do Sul. Nos parece que o nepotismo era uma prática comum por parte de "Cabecinha".

O Estado centralizado era uma marca forte do patrimonialismo para Raymundo Faoro: "O Estado torna-se uma empresa do príncipe, que intervém em tudo, empresário audacioso, exposto a muitos riscos por amor à riqueza e à glória: empresa de paz e empresa de guerra" ${ }^{\natural 3}$. Tudo passava pelo estado, sobretudo a concessão de cargos.

\footnotetext{
${ }^{39}$ GINZBURG, 1990, p. 151.

40 TAUNAY, Afonso de Escragnolle. Documentos sobre o povoamento do Rio Grande do Sul e Santa

Catarina (1711). Jornal do Comércio, Rio de Janeiro, p. 4, 25 Dez. 1932.

${ }^{41}$ PEREIRA, 1984. p. 57.

${ }^{42}$ NASCIMENTO, 1998. p. 27.

${ }^{43}$ FAORO, 1977, p. 38
} 
Revista NEP - Núcleo de Estudos Paranaenses, Curitiba, v.5, n.1, jun. 2019

O mandatário "Cabecinha" imbuído dessa mentalidade não teve dúvida em nomear parentes em funções públicas para se beneficiar. O Estado atuava em todos os âmbitos da via social. É a resistência de um Estado patrimonialista que gera um Estamento burocrático que vai acabar formando grupos que não separam o público do privado. Assim não era estranho para "Cabecinha" nomear seus parentes para exercer atividades judiciárias. A origem do problema estaria na cristalização de um Estado patrimonialista que abre espaço para um Estamento burocrático que coloca seus interesses acima de tudo. Logo:

\begin{abstract}
A corte, povoada de senhores e embaixadores, torna-se o sítio preferido dos comerciantes, todos, porém, acotovelados com a chusma dos pretendentes pretendentes de mercês econômicas, de cargos, capitanias e postos militares. [...] A linhagem vale pouco, menos ainda o merecimento: a conquista ao emprego, ao posto, à dignidade se faz à custa da intriga bem tecida, da conversa doce. ${ }^{44}$
\end{abstract}

Não podemos esquecer da vítima a jovem Ana Lamim casada com Manoel Velho que no momento do acontecido estava separada dele. Da literatura levantada Antonio Roberto Nascimento e o processo de Pires Paradinho apresentam Manoel Velho como primo de "Cabecinha". O restante dos autores não explicita se havia laços de sangue ou não entre eles.

Na sentença de 1721, Pires Pardinho detalha como teria sido o homicídio. Como era de praxe "Cabecinha" sempre contava com a ajuda de seus familiares e escravos nas suas ações. É importante relacionar as interpretações e relatos das fontes afim de reconstruir de como se deu crime.

Pires Pardinho narra que "Cabecinha" e seu bando entre familiares e aliados foram até a casa de João Gonçalves Lamim, irmão de Ana Lamim, armados e aos gritos exigindo que Ana Lamim:

[...] juntasse e fizesse vida com seu marido Manoel Velho, primo do réu, e por esta o duvidar, e não querer fazer por justas causas que tinha, publicava o réu que à força de suas armas o havia de conseguir pois a dita sua mãe Domingas Luiz e seus irmãos a não queriam entregar a seu marido tendo sido notificados

${ }^{44}$ Id. Ibid. 
Revista NEP - Núcleo de Estudos Paranaenses, Curitiba, v.5, n.1, jun. 2019

por monitório, que o dito Manoel Velho alcançara do vigário da vara daquele distrito a esse fim. ${ }^{45}$

"Cabecinha" e seu grupo queriam obrigar Ana Lamim e voltar com Manoel Velho seu marido de quem estava separada. E nem que para isso fosse preciso usar a força das armas. O ato do réu prossegue Pires Pardinho, não fazia sentido em vista de que Manoel Velho já tinha procurado os meios legais para fazer com que Ana voltasse a ser sua esposa e "Cabecinha" queria atropelar todo o procedimento no qual: "Ela podia e devia ser ouvida de sua justiça". ${ }^{46}$ Juntamente com seu bando "Cabecinha" exemplifica a noção de estamento burocrático de Raymundo Faoro:

Esta corporação de poder se estrutura numa comunidade: o estamento. Para a compreensão do fenômeno, observe-se, desde logo, que a ordem social, ao se afirmar nas classes, estamentos e castas, compreende uma distribuição de poder, em sentido amplo - a imposição de uma vontade sobre a conduta alheia. $^{47}$

O que importava para "Cabecinha" e seu grupo que se reivindicavam como um estamento na vila de São Francisco do Sul era estabelecer sua vontade sobre os comportamentos alheios. Em suma se apropriar do Estado e tudo que ele oferecia (cargos, recursos e etc) para acessar os benefícios e vantagens diante do status que adquiria e dessa forma usar o bem público para resolver interesses privados.

Não conseguindo durante a tarde atingir seu objetivo a noite volta com seu irmão o juiz ordinário Miguel Francisco Francisques na casa da família Lamim para que conseguisse convencer Ana Lamim a voltar para seu marido. O outro juiz ordinário João Mor Vieira, parente de "Cabecinha" também buscando contemporizar a situação pediu que "Cabecinha" não fosse até a casa dos Lamim com suas armas e que no dia seguinte trataria de resolver o imbróglio. ${ }^{48} \mathrm{O}$ Capitão-mor enraivecido disse que não iria esperar até o outro dia, então João Mor Vieira foi também a casa de João Gonçalves Lamim quando saia seu amigo e colega juiz Miguel Francisco Francisques que estava extremamente aborrecido por não ter conseguido argumentar com Ana Lamim de modo

\footnotetext{
${ }^{45}$ PARDINHO, 1721. p. 7.

${ }^{46}$ PARDINHO, 1721. p. 8.

${ }^{47}$ FAORO, 1977, p. 58.

${ }^{48}$ Id. Ibid. Por sua vez Lucas Boiteux declara ter sido um tiro de Arcabuz. In: BOITEUX, Lucas Alexandre.
}

Notas para a história catharinense. Typografia da Livraria moderna, 1912. p. 176. 
Revista NEP - Núcleo de Estudos Paranaenses, Curitiba, v.5, n.1, jun. 2019

que a convencesse que era mais razoável voltar ao seu lar. Foi então para a sua casa e retornou armado quando se aproximou da porta da casa de Ana Lamim mata João Mor Vieira que se despedia de João Gonçalves Lamim com um tiro na virilha: “[...] com que logo pediu confissão e gritou sobre o dito seu parceiro o ter morto". 49

Nesse interim entraram na casa "Cabecinha", seu irmão Antonio Francisco Francisques, seus filhos e escravos que pegaram Ana Lamim a força e levaram para a rua e foram informados que Miguel Francisco Francisques também estava morto com um tiro levado nas costas após confrontar-se com João Mor Vieira. Acrescenta-se mais uma morte: “[...] no breve tempo que os réus estiveram na dita casa, que se mostra ter morto Simião Vieyra também já falecido, filho bastardo do dito juiz João [Moreira]". ${ }^{50}$ Ao saber que Miguel Francisco Francisques e João Mor Vieira na verdade mataram-se mutuamente por conta de Ana Lamim, Antonio Francisco Francisques irmão de "Cabecinha" alvejou Ana Lamim na praça perto da Igreja Matriz e com ela já caída bruços:

O réu Domingos [Francisco] lhe fez tiro com um bacamarte nas costas à queima roupa, com que logo ficou morta e as buchas acesas nos vestidos em que ateou fogo, e lhe foi queimando o corpo sem os réus consentirem que o recolhessem da rua, aonde estava toda aquela noite exposto, esperando os réus que algum dos irmãos ou parentes da dita mulher, os quais tinham corrido e perseguindo com vários tiros, lhe viessem recolher o corpo para os matarem o que não conseguiram por todos terem fugido da vila e da fúria dos réus. ${ }^{51}$

Não contente com o cadáver estirado em praça pública de Ana Lamim "Cabecinha" e seus aliados ainda esperavam que seus parentes viessem em busca do corpo e assim teriam chance de mata-los. Ao amanhecer com "Cabecinha" e seu grupo indo embora alguns moradores retiraram o corpo da praça e enterraram assim como os corpos dos juízes Miguel Francisco Francisques e João Mor Vieira que se mataram reciprocamente e também ficaram com seus cadáveres expostos na praça da Igreja Matriz.

Costa Pereira e Luis Gualberto explicam que o motivo do embate foi por causa que os dois disputavam Ana Lamim mesmo sendo casada oficialmente com Manoel Velho apesar de não estarem vivendo como marido e mulher. Temendo um duelo mortal

\footnotetext{
${ }^{49}$ PARDINHO, op. Cit.

${ }^{50}$ Id. Ibid.

51 PARDINHO, 1721. p. 9.
} 
entre Miguel e João "Cabecinha" insistiu que Ana Lamim voltasse a conviver com o marido:

\begin{abstract}
O capitão-mor Domingos Francisco, irmão de Francisco, temendo que os dois rivais tivessem um encontro funesto, mandou chamar Ana Lamim para advertíla do mal que estava cometendo e concitá-la a voltar ao lar que abandonara. Nada demovia, porém Ana Lamim do propósito em que estava, e o capitãomor, sentindo-se desobedecido e furioso com o procedimento irregular da rapariga, e querendo evitar que seu irmão sofresse alguma injúria de João Morzinho como era conhecido o juiz ordinário, rival de Miguel Francisco, ou que este, violento e apaixonado, num ímpeto irrefletido atentassem contra a vida de seu adversário, mandou de novo chamar Ana Lamim para aconselhála a que voltasse ao convívio de seu marido. Esta replicou-lhe que neste particular não podia satisfazer os desejos do capitão-mor e que ia desde aquele dia queixar-se ao juiz, solicitando-lhe o desquite do seu marido. ${ }^{52}$
\end{abstract}

Este era o contexto que seu o desenrolar que resultou nas mortes de Miguel Francisco Francisques, João Mor Vieira, Simião Vieyra e principalmente Ana Lamim. Lucas Boiteux fala de uma beleza em relação a Ana Lamim a ponto dos dois ficarem fascinados por ela e assim teria sido dado a contenda pelo coração da dita Ana Lamim. ${ }^{53}$

Assim como nos primeiros assassínios onde fica claro que "Cabecinha" usou o seu poder e influência para matar seus inimigos e ao mesmo se livrar de qualquer responsabilização diante de acusações futuras que poderia sofrer. Agora mais do que nunca "Cabecinha" tinha usado seu poder estamental para se julgar dono de tudo e de todos e por isso poder intervir no imbróglio. Como se viu tendo um desfecho trágico.

Com essa carga de delitos na conta, "Cabecinha" não poderia passar impune. $\mathrm{O}$ rei Dom João V provava do seu próprio veneno dentro do seu território ultramarino. Ele que outrora se beneficiava do centralismo propiciada pelo patrimonialismo agora se via refém de um súdito que substituiu o poder da Coroa portuguesa em nível local e não demonstrava preocupação com as consequências dos seus crimes. Afinal para Raymundo Faoro: "O chefe governa o estamento e a máquina que regula as relações sociais, a ela vinculadas" $" 54$.

\footnotetext{
${ }^{52}$ GUALBERTO, Luís. 1958, p. 7.

${ }^{53}$ BOITEUX, Lucas Alexandre. Notas para a história catharinense. Typografia. da Livraria moderna, 1912. p. 176.

${ }^{54}$ FAORO, 1977, p. 874.
} 
Revista NEP - Núcleo de Estudos Paranaenses, Curitiba, v.5, n.1, jun. 2019

A seguir todo o processo penal e o respaldo na legislação da época em que Pires Pardinho se ancorou para sentenciar o réu Domingos Francisco Francisques e seu bando formado por seus familiares na maioria, amigos e escravos.

\section{Sentença do réu Domingos Francisco Francisques e seus cumplices}

O réu Domingos Francisco Francisques foi condenado à revelia em 1721 [...] por se ter metido [pelos] matos e não poder prender", ${ }^{55}$ segundo Pires Pardinho. Mais à frente vamos detalhar melhor as tentativas de prisão de "Cabecinha". Retornando a sentença juntando as informações das cartas de junho, agosto e novembro mais a própria sentença que Pires Pardinho todas do ano de 1721 elaboramos uma tabela de modo que fique mais didático para o leitor entender a distribuição das penas:

Tabela 1

\begin{tabular}{|c|c|}
\hline \multicolumn{2}{|c|}{ Tabela com o nome dos réus e penas sentenciadas por Rafael Pires Pardinho } \\
\hline Réu & Pena \\
\hline Domingos Francisco Francisques & Pena Ordinária \\
\hline Antonio Francisco Francisques & Faleceu antes da sentença \\
\hline Miguel (Escravo) & Não consta \\
\hline Pedro (O "Maluco) & Faleceu antes da sentença \\
\hline Ângelo Francisco Francisques & Dez anos de degredo para Angola \\
\hline José Francisco Francisques & Dez anos de degredo para Angola \\
\hline Timóteo Francisco Francisques & Cinco anos de degredo para Angola \\
\hline Antônio Francisco Francisques (sobrinho) & Cinco anos de degredo para Angola \\
\hline José (Escravo) & Cinco anos de Galés \\
\hline Domingos Francisco Francisques (filho) & Absolvido. \\
\hline
\end{tabular}

Fonte: Tabela elaborada com base em: PEREIRA, Carlos da Costa. História de São Francisco do Sul. Florianópolis: Ed. da UFSC; São Francisco do Sul, SC: Prefeitura Municipal, 1984, 2018.

Como se vê a pena de morte foi exclusiva para "Cabecinha". Pires Pardinho declarava que o implicava em pena de morte não só pela morte de Ana Lamim, mas por ter sido o agente causador das mortes dos juízes Miguel Francisco Francisques e João Mor Vieira ao tentar forçar que Ana Lamim reatasse com o marido. Para além disso

\footnotetext{
${ }^{55}$ PARDINHO, 1721. p. 1.
} 
Pardinho partia do principio que Ana Lamim foi cerceada do seu direito de questionar perante a justiça o seu casamento. ${ }^{56}$ Reforça mais uma vez a forma despótica e arrogante que "Cabecinha" que exerceu sua função de Capitão-mor sobretudo no caso de Ana Lamim que depois de terem a assassinado [...] não querendo que o corpo desta se recolhesse e fazendo o estar exposto na rua toda a noite, e depois de queimado com o fogo que se atirou nos fatos". ${ }^{57} \mathrm{O}$ conjunto dos crimes não era favorável a "Cabecinha" e não restou outra alternativa a Pires Pardinho a não ser condena-lo a morte:

\footnotetext{
Pelo que tudo e o mais dos autos consta condeno ao réu Domingos [Francisco] Francisques, a que com baraço e pregão se ia levado pelas ruas públicas ao lugar da forca, aonde se ia enforcado e morra morte natural para sempre, e depois lhe se ia a cabeça a cabeça cortada e separada do corpo, para em um poste alto ser posta na dita vila de Nossa Senhora da Graça, Rio de São [Francisco] do Sul até o tempo o consumir e em duzentos mil réis para as despesas da justiça da Relação do Estado. ${ }^{58}$
}

O ouvidor-geral Pires Pardinho português de nascença incorporava bem o espirito da coroa portuguesa e sabia que ao representar o rei Dom João V devia ser rígido e repressivo ao máximo para evitar que novos perfis autoritários e em desalinhamento com a coroa como o de "Cabecinha" surgissem na vila de São Francisco do Sul e além do mais estava amparado pelas Ordenações Filipinas ao penalizar "Cabecinha" com a forca em via pública e que sua cabeça fosse cortada e salgada e pendurada em um poste como exemplo da autoridade de Portugal.

As Ordenações Filipinas lei máxima no Livro V, título XXXV que trata do "Dos que matão, ou ferem, ou tirão com Arcabuz, ou Bésta" prevê a pena capital: "Qualquer pessoa, que matar outra, ou mandar matar, morra por ello morte natural." 59 Sobre o sentido e proporção dessa pena o jurista Heleno Claudio Fragoso destaca que "[...] o sentido dessa legislação é o da intimidação feroz, puramente utilitária, sem haver

\footnotetext{
${ }^{56}$ PARDINHO, 1721, p. 9.

${ }^{57}$ Id. Ibid.

${ }^{58}$ Id. Ibid.

${ }^{59}$ ORDENAÇÕES FILIPINAS, 1984, p. 1184.
} 
proporção entre as penas e os delitos, confundindo-se os interesses do Estado com os da religião". ${ }^{60}$ Haviam quatro formas de morte:

a)“morte cruel”, em que a vida era tirada lentamente, entremeada de suplícios; b) "morte atroz", nesta acrescentavam-se algumas circunstâncias agravantes à pena capital, como a queima do cadáver, etc.; c) "morte simples", perda da vida mediante degolação, enforcamento; d) "morte civil", em que se eliminava a vida civil e os direitos da cidadania. ${ }^{61}$

O modo usado no caso de "Cabecinha" foi o terceiro tipo denominado como exposto acima "morte simples" por enforcamento e posteriormente degolação. Não causaria espanto se Pires Pardinho usasse a primeira ou a segunda forma de morte dada a carga de crimes do réu e sem esquecer que a legislação refletia o contexto e pensamento da época tendo como diretriz a severidade das penas sem levar em contar proporcionalidade das punições ainda mais se tratando de um súdito que fez tudo para desobedecer a coroa como foram os episódios em torno da figura de "Cabecinha". Sua pena foi confirmada pela Relação da Bahia, o tribunal superior da época. Em suma era o tribunal de $2^{\text {a }}$ instância que confirmava as sentenças das ouvidorias e só ela as penas de morte. É preciso refletir sobre qual era o conceito de crime na sociedade colonial do século XVIII e como se procedia e o andamento de um processo. Desde o século XVII, passando pelo século XVIII o nosso foco até o século XIX a legislação que regulava a sociedade colonial eram as Ordenações Filipinas:

\begin{abstract}
Os crimes iam desde os de "lesa-majestade", "assassinato" e "adultério" a outros mais inusitados, como o de "benzer cães ou outros bichos sem autorização" ou "comprar pão para revender". Na época, as penas eram decididas com base no juízo que se fazia sobre a condição do criminoso, a natureza de seu crime e a condição da vítima". ${ }^{62}$
\end{abstract}

Quando não se entende a lógica e os procedimentos da legislação vigente, o pesquisador terá muitas dificuldades em compreender as sentenças proferidas, os

\footnotetext{
${ }^{60}$ FRAGOSO, Claudio Heleno - Lições de Direito Penal - Parte Geral. Ed. Forense. $4^{\mathrm{a}}$ edição. Rio de Janeiro. 1995, pág. 58.

61 PIERANGELI, José Henrique. Códigos Penais do Brasil. Ed. RT; 2a edição; São Paulo; 2004. p. 57.

${ }^{62}$ GRINBERG, Keila. Processos criminais: a história nos porões dos arquivos judiciários. In: Carla B. Pinsky; Tania Regina de Luca. (Org.). O historiador e suas fontes. 1ed.São Paulo: Contexto, 2009. p. 123.
} 
argumentos de defesa e acusação, qual é o discurso do juiz nos seus textos, quais princípios jurídicos respaldados pela do período ele se vale.

Sem isso fica impossivel dissecar o documento de forma interna e externa. Como Ouvidor-geral e corregedor e acima de tudo português Pires Pardinho tinha a missão de ser implacavel contra os funcionários que não respeitassem os interesses da Coroa. Tentar entender a sentença de Pires Pardinho contudo não se faz analisando apenas o processo em si. É mais do que necessário ampliar o conjunto de fontes e cruza-las para inferencias mais amplas e não isoladas que podem levar a um entendimento equivocado. Um historiador inexperiente que lê apenas o processo de Pires Pardinho e não relaciona com as Ordenações Filipinas tenderá a cair do anacronismo de achar que a pena capital aplicada era desumana e contra a dignidade humana. Ou seja o erro anacronico consistiria em examinar o documento com uma ideia do presente que é a noção de direitos humanos. Não existe documento-verdade assim como processo criminal:

[...] os processos criminais tem necesseriamente contradições, incoerências e mentiras, refletir sobre seu processo de produção é fundamental. Afinal, é impossível descobrirmos, em um processo criminal, "o que realmente se passou". Por maior que seja a tentação, é importante lembrar, sempre, que nós não somos os detetives. Ou melhor, somos um tipo diferente de detetive, cujo objetivo não é descobrir o culpado de um crime. Nossa tarefa é outra". ${ }^{63}$

Um processo criminal pode ter informações valiosas que muitas vezes não achamos em outras fontes. Podem ser encontrados pistas, vestígios e indícios que nos levam a conclusões mais gerais sobre o objeto de estudo.

Nesse sentido há um fato a se notar na sentença. Os indivíduos Pedro filho de "Cabecinha", o escravo mulato de nome Miguel e seu irmão Antonio Francisco Francisques mesmo sendo autores dos assassinatos de Mateus Afonso e Pedro Gomes de Carvalho e de Ana Lamim respectivamente não constam na lista de sentenciados. Durante o relato Pedro e Miguel são citados como os promotores dos homicídios com suspeitas de cumprirem ordens diretas de "Cabecinha", porém na penalização não são mencionados. ${ }^{64}$ Pela leitura sabemos que Pedro tinha falecido antes da sentença. $\mathrm{O}$

\footnotetext{
${ }^{63}$ GRINBERG, Keila, 2009. p. 129.

${ }^{64}$ Caso Pedro tivesse vivo ainda no momento da sentença além do título XXXV seria enquadrado no título XVII: "Dos delitos cometidos aleivosamente". Eram os crimes efetuados de forma traiçoeira enganando a vítima como foi com Pedro Gomes de Carvalho. Pires Pardinho usa inclusive o termo "Aleivosamente".
} 
mesmo se deu na morte de Ana Lamim em que Antonio Francisco Francisques, irmão de "Cabecinha" foi um dos participantes do crime, contudo também não está também lista dos penalizados, pois assim como Pedro já estava falecido. Não tem porquanto maiores informações em que contexto se deram as mortes: se foram de causas naturais ou decorrência de algum evento anômalo. Quanto ao escravo mulato Miguel não temos respostas do que aconteceu e do porquê não foi penalizado. Além da hipótese de estar já falecido em 1721 como os outros envolvidos, devemos recordar que o juiz era Antonio Francisco Francisques irmão do réu "Cabecinha" em 1697 ano do crime tratou de armar o processo de forma que os culpados parecessem inocentes. Por outro lado, Pires Pardinho negou o princípio de que "Cabecinha" teria direito de declarar prescrição dos crimes: [...] tiranizando o réu a mesma justiça naquela vila não pode gozar da prescrição que o direito concede aos réus contra a justiça [...]". ${ }^{65}$ Ser Capitão-mor podia ter seus benefícios, mas na hora de acertar as contas a coroa centralizou em "Cabecinha" a culpa maior de todos os crimes que se envolveu.

Os réus Ângelo Francisco, filho de "Cabecinha", José Francisco Francisques seu possível irmão bastardo que estiveram acompanhando "Cabecinha" no episódio de Ana Lamim receberam a pena de degredo em 10 anos para Angola e a pagar cinquenta mil réis cada um para cobrir as despesas da justiça. Seu outro filho Timóteo Francisco Francisques e seu sobrinho bastardo Antonio Francisco a pena foi mais leve com 5 anos de degredo para Angola para cada um e vinte mil réis a serem pagos a justiça. O escravo José que não dispomos de mais registros e notícias foi condenado a em cinco anos de galés. Como era proibido essa punição para menores de 16 anos é de se presumir que ele José já era de uma idade mais adulta.

Para essas condenações acima dos aliados de "Cabecinha" que tomaram parte na morte de Ana Lamim Pires Pardinho usou como base o título CLX "Dos degredos e degradados":

Mandamos, que os delinquentes, que por suas culpas houverem de ser degradados para lugares certos, em que haja de cumprir seus degredos, se degradarem para o Brasil, ou para os lugares de África, ou para Couto de Castro Marim, ou para as partes da Índia nos casos, em que por nossas Ordenações é posto certo degredo para as ditas partes. [...] E quando as culpas forem de

\footnotetext{
${ }^{65}$ PARDINHO, 1721, p. 7.
} 
Revista NEP - Núcleo de Estudos Paranaenses, Curitiba, v.5, n.1, jun. 2019

qualidade, que não mereçam tanto tempo de degredo, será o degredo para África, ou para Castro-Marim, ou para Galés, ou para fora do Reino, ou fora Vila e termo, segundo as culpas merecerem.

Os cumplices de "Cabecinha" na ótica dele não tiveram participação direta da morte de Ana Lamim exceto Antonio Francisco Francisques já falecido quando da sentença. Desta forma dos cinco acusados todos foram condenados ao degredo para o continente africano com tempos de permanência diferentes. Dois deles em 10 anos e os outros dois em 5 anos. O escravo José caso mais especifico sofreu a sanção de 5 anos de Galés: [...] aonde servirá ao dito Senhor sem soldo, vista a menos prova que contra estes réus resulta da dita devassa."66 A pena de Galés eram trabalhos forçados com os condenados acorrentados pelos pés ou aprisionados obrigados a remar em embarcação denominadas Galé daí o nome.

No século XVIII a prática do degredo atingiu um alcance de destaque: "Como assinala o historiador Charles Boxer, e os relatórios dos governadores da época o confirmam, o fluxo de degredados para Angola tem o seu auge no século XVIII". ${ }^{67}$ A pesquisadora Juliana Diogo Abrahão comenta em seu trabalho a origem dos degredados para Angola:

\footnotetext{
Os principais locais de procedência dos degredados seriam as cidades do Rio de Janeiro, Pernambuco, Bahia, Lisboa, Porto, e Ilha da Madeira, e quem está condenando esses criminosos. Os locais de maior procedência são: Bahia com 341 pessoas, Rio de Janeiro com 255, Lisboa com 239 e Pernambuco com $160 .{ }^{68}$
}

A ouvidoria de São Paulo a qual a vila de São Francisco do Sul não está na lista dos principais locais de procedência. A explicação estaria no processo que era feito com os degredados onde eles faziam uma parada geralmente na Bahia ou no Rio de Janeiro, ou seja, não iam direito para o continente africano explica Juliana Abrahão. Assim o local de procedência não significa a naturalidade do degredado. Em alguns casos: “[...] a procedência e a naturalidade constam do mesmo local" ${ }^{69}$ Evidentemente se o apenado

\footnotetext{
${ }^{66}$ PARDINHO, 1721. p. 10.

${ }^{67}$ PANTOJA, Selma. Inquisição, Degredo e Mestiçagem em Angola no século XVIII. Revista Portuguesa de Ciência das Religiões, Lisboa, 2005, p. 120.

${ }^{68}$ ABRAHÃO, Juliana Diogo. Degredo e reinserção social de degredados, Angola (Século XVIII). Simpósio da ANPUH, Florianópolis, 2015. p. 6.

${ }^{69}$ ABRAHÃO, 2015. p. 6.
} 
Revista NEP - Núcleo de Estudos Paranaenses, Curitiba, v.5, n.1, jun. 2019

fosse natural do Rio de Janeiro por exemplo iria coincidir com o local de procedência. Como a vila de São Francisco do Sul ficou por muito sob os mandos e desmandos de "Cabecinha" sem cumprimento das leis ou fiscalização dos ouvidores e corregedores é esperado que não houvessem registros de processados e degredados. O degredo era considerado uma punição dentro dos princípios das Ordenações Filipinas para o legislador para aqueles que ajudaram direta ou indiretamente o rebelde Domingos Francisco Francisques.

$\mathrm{Na}$ próxima seção iremos tratar das incursões que houveram para prender "Cabecinha" e seus asseclas.

\section{Tentativas de captura do fugitivo "Cabecinha" e seu bando}

Após a condenação Pires Pardinho em seguida faz solicitação para que: "Passem-se as ordens necessárias para os sobreditos réus condenados serem presos e em suas pessoas se poderem executar as ditas penas corporais. E apelo. Paranaguá, vinte e seis de junho de mil setecentos e vinte e um. Raphael Pires Pardinho" ${ }^{70}$ Como se sabe a prisão não pode ser realizada pelo condenado e seu grupo terem se escondido nos matos de modo a ficar difícil sua prisão. ${ }^{71}$

As tentativas, porém, de prender ele e seu bando começam antes do julgamento e pedido de prisão de Pires Pardinho. Desde de 1711 "Cabecinha” já não ocupava mais o cargo de Capitão-mor quando assumiu em seu lugar Agostinho Alves Marinho. Temos essa confirmação porque em 3 de março de 1711 quando da vinda do Sargento-mor Manoel Gonçalves Aguiar foi Agostinho Alves Marinho que se apresentou como Capitão-mor a Manoel Gonçalves Aguiar. Nesse momento Domingos Francisco Francisques e seu pessoal estavam na condição de fugitivos. ${ }^{72}$

Em novembro de 1712 quase dois anos depois da vinda de Manoel Gonçalves de Aguiar o rei Dom João V já demonstrava estar ciente das ações de "Cabecinha" ao responder a carta de Manoel de Manoel Gomes Barboza enviada a Portugal em janeiro do mesmo ano:

\footnotetext{
${ }^{70}$ PARDINHO, 1721, p. 10

${ }^{71}$ Id. ibid.

${ }^{72}$ PEREIRA, 1984, p. 59.
} 
Revista NEP - Núcleo de Estudos Paranaenses, Curitiba, v.5, n.1, jun. 2019

EU EL-REI vos envio muitas saudações. Viu-se a vossa carta de 8 de janeiro deste ano em que dá conta das mortes, injustiças e violências que o Capitãomór do Rio de São Francisco, Domingos Francisco Francisques tem feito e usado com os moradores daquela vila. E parece-me dizer-vos que ao Ouvidor de São Paulo ordeno devassa dos casos todos que o forem de devassa na forma da Lei, prendendo e dando Livramento ao dito Capitão-mór ${ }^{73}$

Dom João V continua reconhecendo que a prisão de Domingos Francisco Francisques seria difícil devido ao seu posto e poder e diante disso solicita todo o apoio necessário para que Manoel Gomes Barboza efetuasse a prisão de "Cabecinha". Também explica que atendendo as reclamações de que o Rio de Janeiro não estava o auxiliando, ordenou ao dito governador que ajudasse em tudo que fosse possível a praça de Santos sob o comando de Manoel Gomes Barboza. O escritor catarinense Affonso de Taunay em 1932 escrevendo para o Jornal do Comércio narrando a povoação do Rio Grande do Sul e de Santa Catarina e descrevendo o terror imposto por Domingos Francisco Francisques fala que: "Tais os despropósitos destes indivíduos que muitos francisquenses se haviam refugiado em Paranaguá e na Ilha de Santa Catarina". 74

Em 1714 no mês de novembro três anos após a primeira incursão e dois anos após as diligencias do rei Dom João V, Manoel Gonçalves de Aguiar voltava dessa vez empenhando na missão de prender "Cabecinha" e seu grupo sobretudo pela morte de Ana Lamim um ano antes em 1713. O nível de terror imposto na vila por "Cabecinha" tinha chegado ao nível máximo com o caso de Ana Lamim, foi o estopim e agora mais do que nunca necessário prendê-lo assim como seus parceiros.

Na sua obra Em Santa Catharina Colonial Taunay também vai na mesma direção: "Chegavam a cada momento os clamores dos povos ao governo fluminense, sobretudo os do S. Francisco do Sul, onde o "Cabecinha" continuava a série das inomináveis violências de que era useiro e vezeiro." $" 75$ Chegou em 23 de novembro de 1714 e passou rapidamente pela vila após conversar com as autoridades, porém

\footnotetext{
73 1712, novembro, 19. CARTA do Rei Dom João V ao governador da praça Carta de D. João V ao governador da praça de Santos ordenando-lhe que dê ao ouvidor-geral de S. Paulo a ajuda necessária para a prisão do capitão-mor do Rio de S. Francisco Domingos Francisco Francisques. Cópia. Letra do séc. XIX.F.G. 238, f. 39 v.

74 TAUNAY, 1932. p. 4.

75 TAUNAY, Afonso de E. Em Santa Catharina Colonial: Capitulo da história do povoamento. São Paulo: Imprensa Oficial do Estado, 1936. p. 37.
} 
Revista NEP - Núcleo de Estudos Paranaenses, Curitiba, v.5, n.1, jun. 2019

prometendo voltar em breve. Em fevereiro de 1715 como prometera retorna vila só que por terra sem avisar ninguém. Tinha motivo para isso: pegar de surpresa "Cabecinha" e seu grupo com inclusão de seu irmão Antonio Francisco Francisques ainda vivo ${ }^{76}$. O mestre de campo pediu a Gonçalves Aguiar prendesse todos os criminosos que aterrorizavam a região. O criminoso era sem dúvida o principal alvo. Com sua escolta rigorosamente escolhida com os seus melhores homens e mais a ajuda de Agostinho Alves Marinho o Capitão-mor da Vila no momento e voluntários empreendeu uma jornada sacrificante atravessando regiões alagadiças e difíceis de se locomover para no fim não ter êxito em deter "Cabecinha". Esperto como era "Cabecinha" e seus amigos e familiares possivelmente estavam refugiados a quilômetros de sua residência mata a dentro há essa altura. O resultado da batida por Manoel Gonçalves de Aguiar a casa de "Cabecinha" foi a seguinte ${ }^{77}$ :

Na batida efetuada, Gonçalves de Aguiar conseguira apenas capturar um escravo chamado Lourenço, pertencente a Antônio Francisques, e apreender cinco bacamartes, uma roda de ralar mandioca e diversos apetrechos de propriedade dos foragidos, e, de regresso à vila, ainda apanhou e levou acorrentados, cerca de nove indivíduos, sendo possível que alguns deles fizessem parte do bando do "Cabecinha". ${ }^{7}$

Lembra Taunay que assim como Bartholomeu Fernandes de Faria, "Cabecinha" tinha uma guarda de criminosos para o proteger. ${ }^{79}$ Não é relatado nenhum depoimento do escravo Lourenço no processo de Pires Pardinho ou mesmo ele é citado, mesmo sendo detido na batida de Manoel Gonçalves de Aguiar. Em relação aos bacamartes pode ter saído de um deles o tiro que matou Ana Lamim. O restante dos materiais deixados para trás devem ter feito parte da estratégia do grupo em carregar o menor peso possível e conseguir caminhar mais rápido e sem deixar pistas.

\footnotetext{
${ }^{76}$ Como já mencionado em 1721 no ato da sentença Pires Pardinho ele já tinha falecido.

${ }^{77}$ O pesquisador Geraldo Hostin ao comparar os bens confiscados de "Cabecinha" com o testamento de Antônio da Fonseca Pinto mais ou menos quarenta anos antes vamos observar que os bens de "Cabecinha" são poucos, indicando que o Capitão-mor devia ser despossuído em relação a Antônio Fonseca Pinto. Hostin fala que não há informações sobre pecuária ou outras atividades econômicas e então ele questiona: "[...] se o principal mandatário do lugar não era rico o que dizer dos outros cidadãos?" (HOSTIN, Geraldo José da Silva. Memórias históricas: Crônicas de navegantes e Capitães-Mores no Sul do Brasil 1658-1737. Editora do autor: São Francisco do Sul, 2018, p. 99). Podemos pensar numa possível decadência da Vila.

${ }^{78}$ PEREIRA, 1984, p. 59.

${ }^{79}$ TAUNAY, 1936. p. 49.
} 
Revista NEP - Núcleo de Estudos Paranaenses, Curitiba, v.5, n.1, jun. 2019

Sobre os nove indivíduos, podemos ficar com o questionamento: será que eles foram arrolados como testemunhas no processo contra "Cabecinha"? Nunca saberemos já que no processo não é dito o nome das testemunhas. Quem sabe em pesquisas futuras essa dúvida seja respondida. O que sabemos é que foram enviados ao Rio de Janeiro, inclusive o escravo Lourenço. Por ter sido o único nomeado parece ter sido o mais destacado dos nove presos. ${ }^{80} \mathrm{O}$ mesmo resultado abaixo do esperado é descrito por Taunay: "Não o encontrou em S. Francisco: homisiara-se desde algum tempo. Deposto, fora do cargo, correndo o seu processo à revelia perante a Relação Bahiana". ${ }^{81}$ A população agradeceu o empenho e a sensação de segurança após a empreitada de Manoel Gonçalves Aguiar.

Cinco anos depois em 1720 um pouco antes de sentença final Pires Pardinho solicitou a arrecadação dos bens do réu Domingos Francisco Francisques que se resumia em: "Terras de outra banda desta vila, na paragem da Olaria, uma prensa de espremer mandioca, uma casa situada na vila, três cadeiras, dois bancos de encosto e um cabide e armas. A casa estava alugada ao vigário D. Antônio Roxadelli, pelo preço de meia pataca por mês". ${ }^{82}$ Houveram outras duas tentativas. A primeira em 1726 pelo ouvidor de Paranaguá Manoel de Sampaio juntamente com seu escrivão Luiz Henrique de Freitas. Dois anos depois em 1728 apenas o escrivão Luiz Henrique de Freitas aventurou-se a deter "Cabecinha" e seus partidários. As duas missões não tiveram sucesso. ${ }^{83}$

Antes da confirmação da sentença pela Relação da Bahia que ratificava as decisões em $1^{\text {a }}$ instância interpelada por Pires Pardinho ${ }^{84}$ "Cabecinha" já estava desaparecido como mostramos acima nas incursões há um bom tempo, tanto é que foi julgado e condenado sempre à revelia. Com a decisão do tribunal havia mais motivos para continuar a se esconder. Por isso nunca tivemos certeza se os pronunciados cumpriram suas penas integralmente. O pouco que se sabe chegou até nós por Lucas Boiteux e seu livro Notas para a História Catarinense em que fala do perdão de João Gonçalves Lamim

\footnotetext{
${ }^{80}$ Id. ibid.

${ }^{81}$ TAUNAY, 1932. p. 4.

${ }^{82}$ PEREIRA, op. cit.

${ }^{83}$ CABRAL, Oswaldo Rodrigues. História de Santa Catarina. Curitiba: Grafipar, 1968. p. 36.

${ }^{84}$ Em 1724 o ouvidor-geral de São Paulo Manoel de Melo Godinho Manso manda carta a Dom João V afirmando que remessa do processo para a Relação da Bahia tão logo puder como "Manda-me [Vossa Majestade] que logo [faça admitir] [para] a Relação da Bahia". Em 1723 o Conselho Ultramarino já havia pedido que Manoel de Melo Godinho Manso fizesse esse procedimento.
} 
Revista NEP - Núcleo de Estudos Paranaenses, Curitiba, v.5, n.1, jun. 2019

irmão de Ana Lamim: "Pelo ano de 1736, o capitão João Gonçalves Lamim por escritura pública, 'deu perdão pela morte de sua irmã Ana Lamim a Antônio Timóteu e Angêlo Francisco Francisques, porque, além de serem de menor idade, andavam pedindo a seu pai e tio que a não a matasse' ${ }^{85}$ Fora essa exceção até o momento não obtivemos mais desdobramentos das sentenças e do paradeiro de cada um dos condenados. Muito lamenta Taunay se tivesse sido diferente o resultado: "Nas 'confortáveis' masmorras coloniais quanto não se arrependeriam os asseclas do "Cabecinha", da fatalidade que os levara a acompanhar-lhe a vida criminosa!" 86 .

Nesse momento as notícias sobre "Cabecinha" e seu bando já tinham cessado bastante. Na verdade, desde 1715 ninguém mais sabia do seu destino ou preferia não falar. O homem que um dia tinha sido o terror da vila agora tinha desaparecido para sempre. Agora sairia dos registros para virar lenda.

\section{Considerações Finais}

Determinadas figuras ou personagens que possuem importância histórica, ao se perpetuarem nos anos, passam a ressoar na memória coletiva da população e ganham assim narrativas diversas, tornam-se figuras folclóricas, mitológicas, o caso de Domingos Francisco Francisques, o vulgo "Cabecinha", segue em certa medida essa regra, mas para além da figura "folclórica" do indivíduo, dotado de grande perversidade e nequícia, “Cabecinha”, enquanto figura histórica, é pouco estudado. Informações acerca de sua vida e contexto ainda são nebulosas, a falta dessas informações deixa lacunas para a suposição de toda a ordem, a vida de "Cabecinha" converge com a História de São Francisco do Sul e, por conseguinte de Santa Catarina.

A documentação pesquisada, além de fornecer a biografia revisada de "Cabecinha”, revela também algumas características jurídicas e administrativas do Império português no início do século XVIII. Isto posto, o artigo além de revisitar a vida de "Cabecinha", evidencia a necessidade de novas pesquisas que possam aprofundar e

\footnotetext{
${ }^{85}$ BOITEUX, 1912, p.176-177.
}

86 TAUNAY, 1936. p. 49. 
Revista NEP - Núcleo de Estudos Paranaenses, Curitiba, v.5, n.1, jun. 2019

revisitar a história dele, assim como contribuir para com a História de São Francisco do Sul e de Santa Catarina.

\section{Referências}

Documentação primária:

1712, novembro, 19. CARTA do Rei Dom João V ao governador da praça de Santos ordenando-lhe que dê ao ouvidor-geral de S. Paulo a ajuda necessária para a prisão do capitão-mor do Rio de S. Francisco Domingos Francisco Francisques. Cópia. Letra do séc. XIX.F.G. 238, f. 39 v.

1721, junho, 26, Paranaguá, CARTA do (ouvidor-geral da capitania de São Paulo), Rafael Pires Pardinho (o rei) Dom João V. AHU, CU, 023-01, Cx. 2, D. 202.

1721, agosto, 26, Paranaguá, CARTA do (ouvidor-geral da capitania de São Paulo), Rafael Pires Pardinho juntamente com a cópia da sentença que proferiu para (o rei) Dom João V. AHU, CU, 023-01, Cx. 2, D. 202

\section{Bibliografia}

BOITEUX, Lucas Alexandre. Notas para a história catharinense. Typografia da Livraria moderna, 1912.

CABRAL, Oswaldo Rodrigues. História de Santa Catarina. Curitiba: Grafipar, 1968.

FAORO, Raymundo. Os donos do poder: formação do patronato político brasileiro. 2 vol. 4 ed. Porto Alegre: Globo, 1977.

GINZBURG, Carlo. "Sinais: raízes de um paradigma indiciário" In: Mitos, emblemas, sinais: Morfologia e História. 1ª reimpressão. São Paulo: Companhia das Letras, 1990.

GUALBERTO, Luís. Domingos Francisco Francisques. O Estado, Florianópolis, 23 fev. 1958.

GUERRA, Luís Bivar. Cem anos de Genealogia (1877-1977). Lisboa: Biblioteca genealógica de Lisboa, 1978.

HOSTIN, Geraldo José da Silva. Memórias históricas: Crônicas de navegantes e Capitães-Mores no Sul do Brasil 1658-1737. Editora do autor: São Francisco do Sul, 2018.

NASCIMENTO, Antonio Roberto. A descendência do Fundador de São Francisco do Sul. Revista do Instituto Histórico e Geográfico de Santa Catarina, Florianópolis, n.17, jan. 1998. 
Revista NEP - Núcleo de Estudos Paranaenses, Curitiba, v.5, n.1, jun. 2019

ORDENAÇÕES FILIPINAS. Lisboa: Calouste Gulbenkian, 1984.

PEREIRA, Carlos da Costa. História de São Francisco do Sul. Florianópolis: Ed. da UFSC; São Francisco do Sul, SC: Prefeitura Municipal, 1984.

TAUNAY, Afonso de Escragnolle. Documentos sobre o povoamento do Rio Grande do Sul e Santa Catarina (1711). Jornal do Comércio, Rio de Janeiro, 25d. 1932.

TAUNAY, Afonso de Escragnolle. Em Santa Catharina Colonial: Capitulo da história do povoamento. São Paulo: Imprensa Oficial do Estado, 1936.

Recebido em: 01 abr. 2019.

Aceito em: 25 jun. 2019. 